\title{
Mechanism of cadmium immobilization in phosphate-amended arable soils
}

\author{
Chuanpit Ruangcharus ${ }^{1+}$, Sung Un $\mathrm{Kim}^{1+}$ and Chang Oh Hong ${ }^{1,2^{*}}$
}

\begin{abstract}
Little is known about the exact mechanism of cadmium (Cd) immobilization by phosphate (P) in arable soil containing low $\mathrm{Cd}$ concentration. This study was designed to describe this mechanism in detail. We determined the phosphorus $(\mathrm{P})$ addition rate allowing $\mathrm{Cd}$ to precipitate as $\mathrm{Cd}$ minerals in $\mathrm{Cd}$-contaminated arable soils and identified the main species of $C d$ minerals formed by the reaction of $C d$ and $P$, using the chemical equilibrium model MINTEQ. To determine the amount of $\mathrm{Cd}$ adsorption to soil adsorbed $\mathrm{P}, 0-10,000 \mathrm{mgPL}^{-1}$ of $\mathrm{K}_{2} \mathrm{HPO}_{4}$ solution was reacted with soil, then the $\mathrm{P}$ adsorbed soil was reacted with a $\mathrm{CdCl}_{2}$ solution $\left(500 \mathrm{mg} \mathrm{Cd} \mathrm{L}^{-1}\right)$. Cadmium might not precipitate as $\mathrm{Cd}$ minerals such as $\mathrm{Cd}_{3}\left(\mathrm{PO}_{4}\right)_{2}$ and $\mathrm{CdCO}_{3}$ with a recommended application rate of $\mathrm{P}$ fertilizer in field scale. Cadmium might be immobilized by $\mathrm{Cd}^{2+}$ adsorption instead of precipitation under a low $\mathrm{P}$ application system. Phosphate adsorption increased the negative charge of soil and $\mathrm{Cd}$ adsorption. The contributions of the increase in $\mathrm{pH}$ - and P-induced negative charges to the total increase in the soil negative charge were 93.2 and $6.8 \%$, respectively. The increase in $\mathrm{Cd}$ adsorption caused by $\mathrm{P}$ adsorption was mainly attributed to the increase in $\mathrm{pH}$-induced negative charge.
\end{abstract}

Keywords: Adsorption, Negative charge, Precipitation, Soil pH, Speciation

\section{Introduction}

Various remediation technologies have been applied to cadmium (Cd)-contaminated arable soils to make the crops grown in these soils suitable for human consumption [1-6]. Many studies on Cd chemical immobilization in arable soils using phosphate $(\mathrm{P})$ fertilizer have been conducted. It is well known that P materials are effective in reducing the bioavailability of $\mathrm{Cd}$ in soils [7-11].

The immobilization of Cd with $\mathrm{P}$ compounds in soils is caused by various mechanism: (i) the formation of $\mathrm{Cd}$ minerals such as $\mathrm{Cd}_{3}\left(\mathrm{PO}_{4}\right)_{2}$; (ii) $\mathrm{Cd}^{2+}$ adsorption induced by P; (iii) cation exchange; and (iv) surface complexation. Indeed, several studies observed that $\mathrm{Cd}$ was immobilized with $\mathrm{P}$ through forming a compound mineral with

\footnotetext{
*Correspondence: soilchem@pusan.ac.kr

${ }^{\dagger}$ Chuanpit Ruangcharus and Sung Un Kim are contributed equally to this work

${ }^{1}$ Department of Life Science and Environmental Biochemistry, Pusan

National University, Miryang 50463, Republic of Korea

Full list of author information is available at the end of the article
}

varying concentrations of these two elements. However, others reported that the precipitation of a Cd-P mineral did not occur under their experimental conditions $[12,13]$. Some researchers reported that the addition of $\mathrm{P}$ immobilized $\mathrm{Cd}$ by increasing its adsorption onto the surface of soil colloids [4,14, 15], but did not elucidate the exact pathway of P-induced $\mathrm{Cd}^{2+}$ adsorption. In a previous study [4], we suggested that $\mathrm{Cd}$ might not be precipitated as Cd-P minerals under $1,600 \mathrm{mg} \mathrm{P} \mathrm{kg}^{-1}$ of $\mathrm{P}$ addition in soil containing low $\mathrm{Cd}$ concentration (total Cd: $5.57 \mathrm{mg} \mathrm{kg}^{-1}$ ). In such soil conditions, an increase in the $\mathrm{pH}$-induced negative charge of soil could play an important role in the immobilization of Cd. However, we did not determine the soil condition under which $\mathrm{Cd}$ could precipitate with $\mathrm{P}$ addition and did not investigate the exact role of a $\mathrm{pH}$-induced negative charge in $\mathrm{Cd}$ immobilization. So far, the exact mechanism of $\mathrm{Cd}$ immobilization with $\mathrm{P}$ in arable soils containing low $\mathrm{Cd}$ concentration remains poorly understood.

Therefore, this study was designed to investigate the mechanism of $\mathrm{Cd}$ immobilization by $\mathrm{P}$ in the arable soil 
containing low $\mathrm{Cd}$ concentration, by estimating (1) the $\mathrm{P}$ addition rate under which $\mathrm{Cd}$ could precipitate as a $\mathrm{Cd}-\mathrm{P}$ mineral and identify the main species of $\mathrm{Cd}$ minerals formed by the reaction of $\mathrm{Cd}$ and $\mathrm{P}$; (2) the contribution of negative charge induced by $\mathrm{P}$ to $\mathrm{Cd}^{2+}$ adsorption in soil.

\section{Materials and methods}

\section{Incubation test for the precipitation of cadmium}

\section{and phosphate}

An arable soil located near the Bongsan gold mine area in Hapcheon, South Korea $\left(128^{\circ} 01^{\prime} \mathrm{N}\right.$ and $\left.34^{\circ} 37^{\prime} \mathrm{E}\right)$ was collected for the precipitation test. The total $\mathrm{Cd}$ concentration in this soil was $5.57 \mathrm{mg} \mathrm{kg}^{-1}$, which exceeded the warning criteria for $\mathrm{Cd}$ in the arable soil established by the Korean Soil Environmental Conservation Act [16]. The chemical and physical properties of the collected arable soil are shown in Table 1.

To determine the suitable $\mathrm{P}$ addition rate to induce $\mathrm{Cd}$ precipitation as Cd-P minerals, the effects of $\mathrm{P}$ addition rate on the solubility of $\mathrm{Cd}$ minerals were investigated in this study. A 500-g soil sample was mixed with 0, 200, 400, 800, 1600, 3200, 8000, and 16,000 $\mathrm{mg} \mathrm{P} \mathrm{kg}^{-1}$ of $\mathrm{K}_{2} \mathrm{HPO}_{4}$ in a plastic beaker and placed in the dark at $25{ }^{\circ} \mathrm{C}$ for 8 weeks. Distilled water was added to fill up $70 \%$ of the soil pore volume. Soil water content was maintained by periodically weighing the beakers and

Table 1 Selected chemical and physical properties of soil for precipitation and adsorption test

\begin{tabular}{|c|c|c|}
\hline Items & $\begin{array}{l}\text { Cd-contaminated } \\
\text { soil } \\
\text { for precipitation } \\
\text { test }\end{array}$ & $\begin{array}{l}\text { Uncontaminated } \\
\text { soil } \\
\text { for adsorption } \\
\text { test }\end{array}$ \\
\hline $\mathrm{pH}\left(1: 5\right.$ with $\left.\mathrm{H}_{2} \mathrm{O}\right)$ & 5.20 & 6.97 \\
\hline Organic matter $\left(\mathrm{g} \mathrm{kg}^{-1}\right)$ & 48.9 & 10.2 \\
\hline $\begin{array}{l}\text { Available phosphorus (mg } \\
\mathrm{kg}^{-1} \text { ) }\end{array}$ & 10.1 & 25.3 \\
\hline $\begin{array}{l}\text { Cation exchange capacity } \\
\left(\mathrm{cmol}_{\left.\mathrm{C}^{-} \mathrm{kg}^{-1}\right)}\right.\end{array}$ & 6.9 & 11.9 \\
\hline \multicolumn{3}{|c|}{ Exchangeable cation $\left(\mathrm{cmol}_{C} \mathrm{~kg}^{-1}\right)$} \\
\hline K & 0.17 & 0.9 \\
\hline $\mathrm{Ca}$ & 3.97 & 7.8 \\
\hline $\mathrm{Mg}$ & 0.87 & 0.9 \\
\hline \multicolumn{3}{|l|}{ Particle size distribution (\%) } \\
\hline Clay & 6.1 & 16.4 \\
\hline Silt & 35.0 & 23.3 \\
\hline Sand & 58.9 & 55.4 \\
\hline Soil texture & Sandy loam & Clay loam \\
\hline Total Cd $\left(\mathrm{mg} \mathrm{kg}^{-1}\right)$ & 5.57 & $\operatorname{tr}$ \\
\hline $\begin{array}{l}1 \mathrm{M} \mathrm{NH}_{4} \mathrm{OAc} \text { extractable } \mathrm{Cd} \\
\left(\mathrm{mg} \mathrm{kg}^{-1}\right)\end{array}$ & 1.45 & $\operatorname{tr}$ \\
\hline
\end{tabular}

tr trace adjusting the weight by adding distilled water. Triplicates were arranged in a completely randomized design in an incubator.

\section{Phosphate adsorption}

For the $\mathrm{P}$ and $\mathrm{Cd}$ adsorption test, uncontaminated arable soil was collected from the experimental farm of Pusan National University, Miryang, South Korea $\left(128^{\circ} 43^{\prime} \mathrm{N}\right.$ and $35^{\circ} 30^{\prime} \mathrm{E}$ ). The physical and chemical properties of the studied soil are also given in Table 1.

To adsorb $\mathrm{P}$ onto the uncontaminated soil, a 1-g soil sample was reacted with $20 \mathrm{ml}$ of $0-10,000 \mathrm{mg} \mathrm{P} \mathrm{L}^{-1}$ $\left(\mathrm{K}_{2} \mathrm{HPO}_{4}\right)$ solution without controlling solution $\mathrm{pH}$ and shaken at $25{ }^{\circ} \mathrm{C}$ for $48 \mathrm{~h}$. Solution $\mathrm{pH}$ condition is a significant factor affecting adsorptions of $\mathrm{P}$ and $\mathrm{Cd}$. We assumed that results of the test could be derived from the wrong thing, if adsorption test was conducted in controlled $\mathrm{pH}$ condition. For this reason, solution $\mathrm{pH}$ was not controlled in the test. The amount of $\mathrm{P}$ adsorbed was calculated by subtracting its final concentration in the equilibrium solution from its initial concentration. The adsorption test was carried out in six replicates. After shaking for $48 \mathrm{~h}$, the soil residues were rinsed with $20 \mathrm{ml}$ of $95 \%$ ethyl alcohol; three replicates were used to analyze for the negative charge of the soil and the other three were used to measure the amount of adsorbed $\mathrm{Cd}$.

\section{Cadmium adsorption}

The soil residues mentioned earlier were reacted with $20 \mathrm{ml}$ of $500 \mathrm{mg} \mathrm{Cd} \mathrm{L}^{-1}\left(\mathrm{CdCl}_{2}\right)$ solution and shaken at $25{ }^{\circ} \mathrm{C}$ for $48 \mathrm{~h}$ to determine the amount of $\mathrm{Cd}$ adsorbed by $\mathrm{P}$ fixed to the soil. The $\mathrm{Cd}$ adsorption capacity was calculated by subtracting its final concentration in the equilibrium solution from its initial concentration.

\section{Determination of $\mathrm{pH}$-induced negative charge and phosphate-induced negative charge}

The amount of $\mathrm{Cd}$ adsorbed to $\mathrm{P}$ added to the soil could be dependent on the change in soil negative charge brought about by $\mathrm{P}$ adsorption. An increase in the negative charge of the soil caused by $\mathrm{P}$ adsorption could be attributed to corresponding increases in (1) the $\mathrm{pH}$ dependent charge by specific adsorption of $\mathrm{P}(\mathrm{pH}-$ induced negative charge) and (2) negative charge from adsorbed orthophosphate (P-induced negative charge). Therefore, we determined the contribution of each of the $\mathrm{pH}$-induced negative charge and $\mathrm{P}$-induced negative charge to the total increase in negative charge of the soil elicited by $\mathrm{P}$ adsorption.

The soil used for the $\mathrm{P}$ and $\mathrm{Cd}$ adsorption test was used to determine the contribution of $\mathrm{pH}$-induced negative charge in the soil. $25 \mathrm{ml}$ of distilled water was added to $5 \mathrm{~g}$ of the soil and shaken in a polyethylene centrifuge 
tube at $25{ }^{\circ} \mathrm{C}$ until the $\mathrm{pH}$ was adjusted to $\mathrm{pH}$ between 3 and 10 using either $0.1 \mathrm{M} \mathrm{NaOH}$ or $\mathrm{HCl}$. After centrifuging for $10 \mathrm{~min}$ at $5000 \mathrm{rpm}$, the supernatant solutions were decanted and $20 \mathrm{ml}$ of $95 \%$ ethyl alcohol was added to rinse the soils before analyzing the $\mathrm{pH}$-induced negative charge of the soil.

The phosphate-induced negative charge was calculated by subtracting $\mathrm{pH}$-induced negative charge obtained at equilibrial $\mathrm{P}$ adsorption from the total negative charge attained at $\mathrm{P}$ adsorption equilibrium.

\section{Cd-mineral speciation}

The Visual MINTEQ (ver 2.23) was used to predict the precipitation or dissolution of $\mathrm{Cd}$ minerals such as $\mathrm{Cd}_{3}\left(\mathrm{PO}_{4}\right)_{2}, \mathrm{CdCO}_{3}$, and $\mathrm{Cd}(\mathrm{OH})_{2}$. The input parameters were the respective concentrations of cations and anions in the soil solution. The concentration of dissolved organic carbon (DOC), ionic strength, $\mathrm{pH}$, and temperature $\left(25^{\circ} \mathrm{C}\right)$ were also inputted. In this study, we assumed a constant $\mathrm{CO}_{2}$ concentration of $0.003 \mathrm{~atm}$.

\section{Chemical analysis}

The chemical properties of the collected soils $(<2 \mathrm{~mm})$ were analyzed using the following methods: $\mathrm{pH}$ (1:5 with $\mathrm{H}_{2} \mathrm{O}$ ), organic matter content [17], and concentrations of exchangeable $\mathrm{Ca}^{2+}, \mathrm{Mg}^{2+}$, and $\mathrm{K}^{+}\left(1 \mathrm{M} \mathrm{NH}_{4}\right.$-acetate $\mathrm{pH}$ 7.0, AA, Shimazu 660). The available P content was determined using the Lancaster method [18]. The negative charge of the soil was measured using $0.1 \mathrm{M} \mathrm{NaCl}$ after performing Schofield's ion retention method [19]. The concentrations of cations in the soil solution were measured using an inductively coupled plasma-optical emission spectrophotometer (ICP-OES, Perkin Elmer Model OPTIMA 4300 DV, Shelton USA). The anions in the soil solution were quantified using an ion chromatograph (IC, Dionex Corporation Model ICS-2000 IC, USA). DOC was quantified using a TOC analyzer (Total Organic Carbon Analyzer Shimadzu Model TOC-VCPN, Japan).

After the $\mathrm{P}$ adsorption test, the $\mathrm{pH}$ of the reacted solution was measured using a $\mathrm{pH}$ meter. The concentration of $\mathrm{P}$ in the equilibrium solution was measured spectrophotometrically at $880 \mathrm{~nm}$ [20]. After the Cd adsorption test, $\mathrm{Cd}$ concentration in the equilibrium solution was measured using ICP-OES.

\section{Results and discussion}

\section{Precipitation of cadmium with phosphate}

The $\mathrm{pH}$ of the soil solution increased with increasing $\mathrm{K}_{2} \mathrm{HPO}_{4}$ concentrations (Table 2). That was because the hydroxyl $\left(\mathrm{OH}^{-}\right)$group was released into the soil solution when the specific adsorption of $\mathrm{P}$ to the edge of the crystals of clay minerals occurred. Log activity of
$\mathrm{CO}_{3}{ }^{2-}$ increased significantly as more $\mathrm{K}_{2} \mathrm{HPO}_{4}$ was added, corresponding to an increase in soil $\mathrm{pH}$. The dissociation of carbonic acid in the soil solution is represented in the following equation:

$$
\mathrm{H}_{2} \mathrm{CO}_{3} \leftrightarrow \mathrm{H}^{+}+\mathrm{HCO}_{3}^{-} \leftrightarrow \mathrm{H}^{+}+\mathrm{CO}_{3}^{2-}
$$

where $\mathrm{pK}_{\mathrm{a} 1}$ and $\mathrm{pK}_{\mathrm{a} 2}$ in carbonic acid are 6.36 and 10.33, respectively. Very few cadmium carbonate $\left(\mathrm{CdCO}_{3}\right)$ molecules can form in acidic soil as the activity of $\mathrm{CO}_{3}{ }^{2-}$ is low, but this increases in alkaline soil, allowing more $\mathrm{CdCO}_{3}$ molecules to form [21]. The log activity of $\mathrm{H}_{2} \mathrm{PO}_{4}{ }^{-}$increased up to the peak concentration of $1600 \mathrm{mg} \mathrm{P} \mathrm{kg}^{-1}$, but decreased afterwards as more $\mathrm{K}_{2} \mathrm{HPO}_{4}$ was added (Table 2). This change is related to an increase in soil pH as more $\mathrm{K}_{2} \mathrm{HPO}_{4}$ is added. The dissociation of phosphoric acid in soil solution is represented in the following equation:

$$
\mathrm{H}_{3} \mathrm{PO}_{4} \leftrightarrow \mathrm{H}^{+}+\mathrm{H}_{2} \mathrm{PO}_{4}^{-} \leftrightarrow \mathrm{H}^{+}+\mathrm{HPO}_{4}^{2-} \leftrightarrow \mathrm{H}^{+}+\mathrm{PO}_{4}^{3-}
$$

where $\mathrm{pK}_{\mathrm{a} 1}, \mathrm{pK}_{\mathrm{a} 2}$, and $\mathrm{pK}_{\mathrm{a} 3}$ of phosphoric acid are $2.15,7.20$, and 12.35 , respectively. Therefore, $\mathrm{H}_{2} \mathrm{PO}_{4}{ }^{-}$is the predominant chemical species of phosphoric acid in the $\mathrm{pH}$ range of 2.15-7.20. However, $\mathrm{HPO}_{4}{ }^{2-}$ dominates above $\mathrm{pH} 7.20$ [21]. The log activity of $\mathrm{H}_{2} \mathrm{PO}_{4}{ }^{-}$increased up to $1,600 \mathrm{mg} \mathrm{P} \mathrm{kg}{ }^{-1}$ as more $\mathrm{K}_{2} \mathrm{HPO}_{4}$ was added, as the solution $\mathrm{pH}$ was below 7.20 (and hence $\mathrm{H}_{2} \mathrm{PO}_{4}{ }^{-}$was predominant) (Table 2). However, it decreased when we added more than $1,600 \mathrm{mg} \mathrm{P} \mathrm{kg}{ }^{-1}$ of $\mathrm{K}_{2} \mathrm{HPO}_{4}$, as soil $\mathrm{pH}$ increased above 7.20 , in which $\mathrm{HPO}_{4}{ }^{2-}$ is predominant.

The results from the calculated $\mathrm{Cd}$ solubility diagram (Fig. 1) suggest that $\mathrm{CdCO}_{3}$ might control the solubility of $\mathrm{Cd}$ at $8000 \mathrm{mg} \mathrm{P} \mathrm{kg}{ }^{-1}$ of $\mathrm{K}_{2} \mathrm{HPO}_{4}$ addition. When $\mathrm{pH}$ exceeds 7.5; depending on $\mathrm{CO}_{2}(\mathrm{~g})$, $\mathrm{Cd}^{2+}$ activity is limited by $\mathrm{CdCO}_{3}$ concentration [21]. Soil pH was 8.29 with $8000 \mathrm{mg} \mathrm{P} \mathrm{kg}^{-1}$ of $\mathrm{K}_{2} \mathrm{HPO}_{4}$ addition (Table 2) and the soil

Table 2 Calculated activities of $\mathrm{Cd}^{2+}, \mathrm{H}_{2} \mathrm{PO}_{4}{ }^{-}$, and $\mathrm{CO}_{3}{ }^{2-}$, as well as the ionic strength and $\mathrm{pH}$ of soil solutions amended with different rates of $\mathrm{K}_{2} \mathrm{HPO}_{4}$ after eight weeks

\begin{tabular}{|c|c|c|c|c|c|}
\hline \multirow{2}{*}{$\begin{array}{l}\mathrm{K}_{2} \mathrm{HPO}_{4} \text { addition } \\
\left(\mathrm{mg} \mathrm{Pg}^{-1}\right)\end{array}$} & \multirow[t]{2}{*}{$\mathrm{pH}$} & \multirow{2}{*}{$\begin{array}{l}\text { lonic } \\
\text { strength } \\
\text { (M) }\end{array}$} & \multicolumn{3}{|c|}{ log activity $\left(\mathrm{mol} \mathrm{L}^{-1}\right)$} \\
\hline & & & $\mathrm{Cd}^{2+}$ & $\mathrm{H}_{2} \mathrm{PO}_{4}^{-}$ & $\mathrm{CO}_{3}{ }^{2-}$ \\
\hline 0 & 5.20 & 0.019 & -5.614 & -5.571 & -9.426 \\
\hline 400 & 5.97 & 0.066 & -7.202 & -3.165 & -7.679 \\
\hline 800 & 6.42 & 0.097 & -7.469 & -2.570 & -6.828 \\
\hline 1600 & 7.03 & 0.117 & -7.878 & -1.787 & -5.799 \\
\hline 3200 & 7.46 & 0.286 & -7.795 & -1.992 & -4.841 \\
\hline 8,000 & 8.29 & 0.772 & -7.438 & -2.543 & -3.624 \\
\hline 16,000 & 8.94 & 1.543 & -7.128 & -2.955 & -2.097 \\
\hline
\end{tabular}
of incubation 
solution was supersaturated with respect to only $\mathrm{CdCO}_{3}$. However, the soil solution was supersaturated with respect to both $\mathrm{CdCO}_{3}$ and $\mathrm{Cd}_{3}\left(\mathrm{PO}_{4}\right)_{2}$ under $16,000 \mathrm{mg} \mathrm{P}$ $\mathrm{kg}^{-1}$ of $\mathrm{P}$ addition (Fig. 1). In general, ions in a given solution can precipitate if the IAP of ion-induced minerals is higher than the mineral solubility product $\left(\mathrm{K}_{\mathrm{sp}}\right)$ [22]. Log IAP values of $\mathrm{Cd}_{3}\left(\mathrm{PO}_{4}\right)_{2}$ were -30.7 with $16,000 \mathrm{mg}$ $\mathrm{P} \mathrm{kg}^{-1}$ of $\mathrm{K}_{2} \mathrm{HPO}_{4}$ addition and higher than $\mathrm{K}_{\mathrm{sp}}$ values $(-32.6)$ of $\mathrm{Cd}_{3}\left(\mathrm{PO}_{4}\right)_{2}$. This implies that $\mathrm{Cd}$ might precipitate as $\mathrm{Cd}_{3}\left(\mathrm{PO}_{4}\right)_{2}$ under $16,000 \mathrm{mg} \mathrm{P} \mathrm{kg}{ }^{-1}$ conditions. Some studies reported formation of $\mathrm{Cd}_{3}\left(\mathrm{PO}_{4}\right)_{2}$ in $\mathrm{Cd}$-contaminated soils amended with a suitable concentration of $P$ [23, 24]. The application of large amounts of $P$ fertilizer can release $P$ from the arable land and subsequently, cause eutrophication of nearby water bodies. For instance, a concentration of $33.5 \mathrm{~kg} \mathrm{P} \mathrm{ha}^{-1}$ of P fertilizer is recommended for radish cultivation in Korea [25], using a product concentration of ca. $18.6 \mathrm{mg} \mathrm{P} \mathrm{kg}^{-1}$. In this study, the soil solution was undersaturated compared to $\mathrm{Cd}_{3}\left(\mathrm{PO}_{4}\right)_{2}$ and $\mathrm{CdCO}_{3}$ below $400 \mathrm{mg} \mathrm{P} \mathrm{kg}{ }^{-1}$ (low $\mathrm{P}$ addition) and $\mathrm{Cd}$ might not precipitate as $\mathrm{Cd}_{3}\left(\mathrm{PO}_{4}\right)_{2}$ or $\mathrm{CdCO}_{3}$ (Fig. 1). As a result, Cd solubility might be controlled by other mechanisms rather than precipitation under low $\mathrm{P}$ application systems.

\section{Phosphate adsorption}

Soil phosphate adsorption increased as the P equilibrium concentration increased (Fig. 2). In general, the P adsorption occurred with an L-curve type on the soil surface in the controlled $\mathrm{pH}$ condition. However, a C-curve type of $\mathrm{P}$ adsorption was observed in this study, probably due to changes in the soil solution $\mathrm{pH}$ depending on the concentration of $\mathrm{K}_{2} \mathrm{HPO}_{4}$. In this study, the $\mathrm{P}$ adsorption

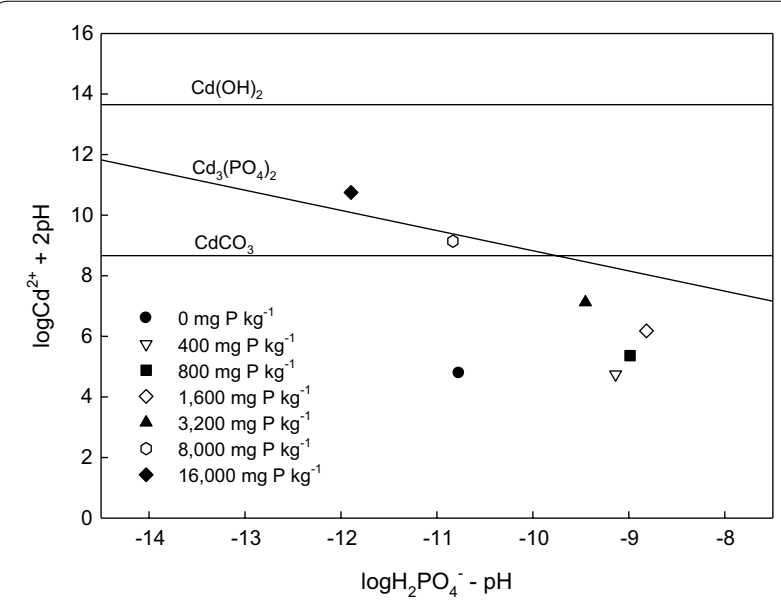

Fig. 1 Cadmium solubility diagram with soil solution speciation by increasing $\mathrm{K}_{2} \mathrm{HPO}_{4}$ addition rate after 8 weeks of incubation at $25^{\circ} \mathrm{C}$. The $\mathrm{CdCO}_{3}$ line assumes $\mathrm{CO}_{2}(\mathrm{~g})=10^{-2.5} \mathrm{M}$ experiment was conducted without controlling solution $\mathrm{pH}$ to understand $\mathrm{P}$ dynamics under the natural soil condition in which $\mathrm{P}$ is specifically adsorbed or precipitated with cations. The final $\mathrm{pH}$ of equilibrium solution increased with increasing adsorbed $\mathrm{P}$ up to $689 \mathrm{mmol}_{\mathrm{c}} \mathrm{P}$ $\mathrm{kg}^{-1}$ of adsorbed $\mathrm{P}$, but there was no further increase in final $\mathrm{pH}$ with additional $\mathrm{P}$ adsorption (Fig. 3). The final $\mathrm{pH}$ of equilibrium solution was 8.71 at $689 \mathrm{mmol}_{\mathrm{c}} \mathrm{P} \mathrm{kg}^{-1}$ of adsorbed $\mathrm{P}$. The $\mathrm{pH}$ of the soil solution increased as more $\mathrm{OH}^{-}$was released into the soil solution through ligand exchange when specific $\mathrm{P}$ adsorption occured. We assumed that the maximum amount ofshared charge by sharing the $\mathrm{P}$ adsorption in the studied soil was $689 \mathrm{mmol}_{\mathrm{c}} \mathrm{P} \mathrm{kg}^{-1}$, as the final $\mathrm{pH}$ was highest under this specific concentration of adsorbed P. Phosphate removal from the above equilibrium solution might be attributed to $\mathrm{P}$ precipitation with calcium in alkaline $\mathrm{pH}$ conditions, instead of specific adsorption of P (Fig. 2).

The trend in the soil negative charge recorded after reacting with $\mathrm{P}$ was similar to that of the final $\mathrm{pH}$ of equilibrium solution (Fig. 4). The soil negative charge was $120 \mathrm{mmol}_{\mathrm{c}} \mathrm{kg}^{-1}$ in the control, increased up to $164 \mathrm{mmol}_{\mathrm{c}} \mathrm{kg}^{-1}$ at $689 \mathrm{mmol}_{\mathrm{c}} \mathrm{P} \mathrm{kg}^{-1}$ of adsorbed P. This implies that total $44 \mathrm{mmol}_{\mathrm{c}} \mathrm{kg}^{-1}$ of soil negative charge was increased by $\mathrm{P}$ adsorption. This increase in soil negative charge by $\mathrm{P}$ adsorption could be attributed to two reasons, first, the increase in $\mathrm{pH}$-induced negative charge and second, the increase in P-induced negative charge. Phosphate adsorption could increase the pH-induced soil negative charge as $\mathrm{OH}^{-}$was released from the edge of the crystals of clay minerals when specific adsorption of $\mathrm{P}$ occurred. Furthermore, the negative charge of the oxide group contained in $\mathrm{P}$ itself could contribute to the increase in soil negative charge. Each oxygen $\left(\mathrm{O}^{-2}\right)$ in the orthophosphate $\left(\mathrm{PO}_{4}{ }^{3-}\right)$ has -0.75 of shared charge

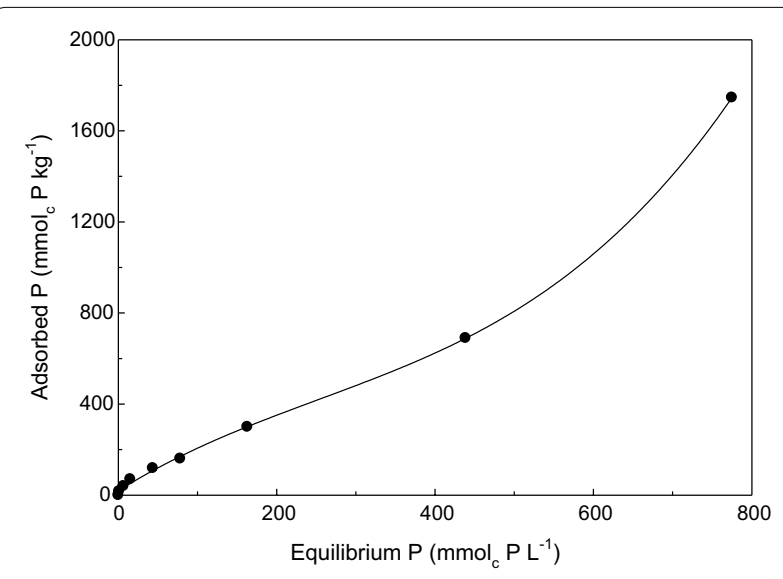

Fig. 2 Phosphate adsorption characteristics of the selected clay loam soil at $25^{\circ} \mathrm{C}$ 


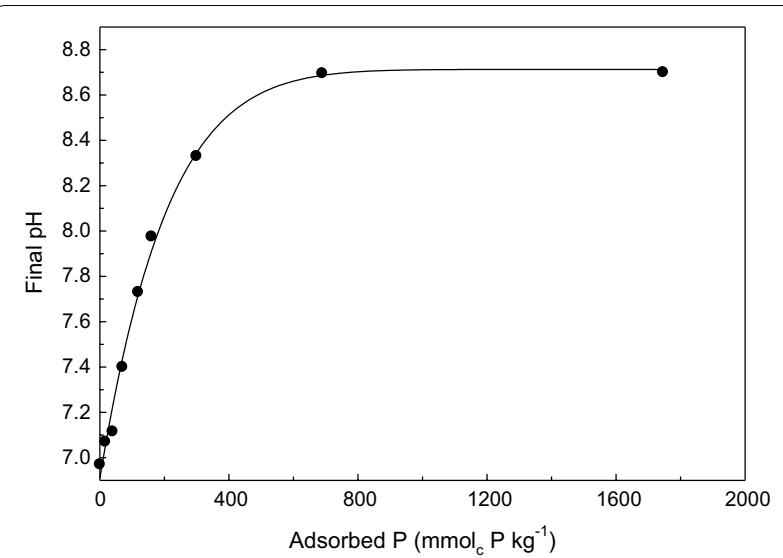

Fig. 3 Final $\mathrm{pH}$ of equilibrium solution after phosphate adsorption

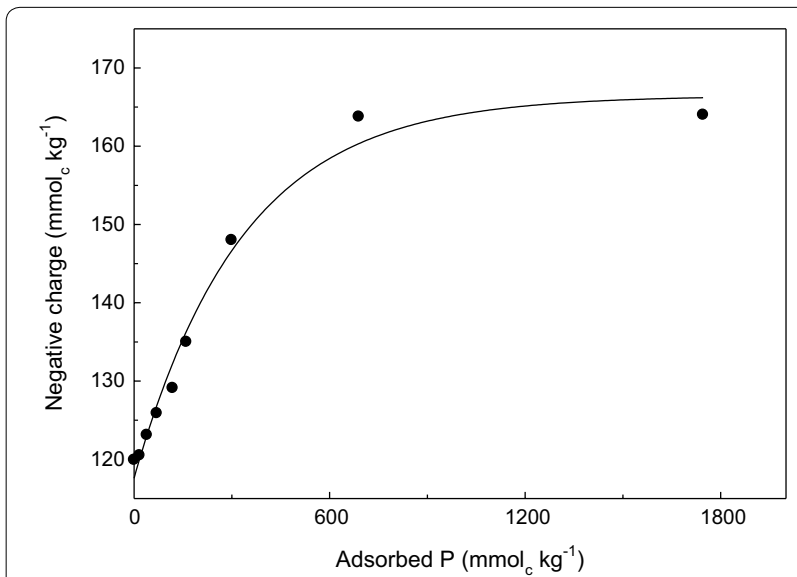

Fig. 4 Changes in soil negative charge due to increased phosphate adsorption to clay loam soil at $25^{\circ} \mathrm{C}$

by sharing the charge with the $\mathrm{P}^{+5}$ atom. This "shared charge" is determined by dividing the valence of $\mathrm{P}$ by the number of bonded $\mathrm{O}$ atoms [26].

\section{Cadmium adsorption}

The pattern of $\mathrm{Cd}$ adsorption to $\mathrm{P}$ adsorbed soil was similar to that of the soil negative charge (Fig. 5). Cadmium adsorption was $139 \mathrm{mmol}_{\mathrm{c}} \mathrm{kg}^{-1}$ in the control and increased up to $161 \mathrm{mmol}_{\mathrm{c}} \mathrm{kg}^{-1}$ at $689 \mathrm{mmol}_{\mathrm{c}} \mathrm{P} \mathrm{kg}^{-1}$ of adsorbed $\mathrm{P}$, implying that a total of $22 \mathrm{mmol}_{\mathrm{c}} \mathrm{kg}^{-1}$ of $\mathrm{Cd}$ was adsorbed onto the negative site in the soil. The $\mathrm{Cd}$ maximal adsorption corresponded to maximal $\mathrm{P}$ adsorption $\left(689 \mathrm{mmol}_{\mathrm{c}} \mathrm{P} \mathrm{kg}^{-1}\right)$, possibly implying that Cd possibly occupied all adsorption sites made by $\mathrm{P}$ adsorption, and that the maximum concentration of $\mathrm{P}$ adsorbed soil did not provide more $\mathrm{Cd}$ adsorption sites. However, the negative charge at $\mathrm{P}$ maximal adsorption $\left(689 \mathrm{mmol}_{\mathrm{c}}\right.$ $\mathrm{kg}^{-1}$ ) was $164 \mathrm{mmol}_{\mathrm{c}} \mathrm{kg}^{-1}$ (Fig. 4) and was not the same as the $\mathrm{Cd}$ maximal adsorption $\left(161 \mathrm{mmol}_{\mathrm{c}} \mathrm{kg}^{-1}\right)$ (Fig. 5). Moreover, $\mathrm{Cd}$ adsorption did not have a significant correlation with $\mathrm{P}$ adsorption but showed a significantly positive correlation with soil negative charge $\left(r=0.841^{\text {w"t }}\right)$ (Table 3). Based on the above results, we assumed that $\mathrm{Cd}$ was not adsorbed to all adsorption sites created by adsorbed P.

\section{Contribution of $\mathrm{pH}$-induced negative charge to $\mathrm{Cd}$ adsorption}

The soil negative charge with $\mathrm{P}$ adsorption was found to increase as both $\mathrm{pH}$ - and P-induced negative charges increased. The soil negative charge had a more significant positive correlation with the final $\mathrm{pH}\left(\mathrm{r}=0.977^{* * *}\right)$ than with $\mathrm{P}$ adsorption $\left(\mathrm{r}=0.830^{\text {st* }}\right)$ (Table 3), implying that changes in soil $\mathrm{pH}$ caused by $\mathrm{P}$ adsorption could explain changes in negative charge better than that of $\mathrm{P}$ adsorption itself. The soil negative charge used for the adsorption test increased significantly with increasing soil $\mathrm{pH}$ (in the range of $\mathrm{pH} 3.1-10.0$; Fig. 6). The soil negative charge was $120 \mathrm{mmol}_{\mathrm{c}} \mathrm{kg}^{-1}$ at $\mathrm{pH} 6.97$ which was the initial $\mathrm{pH}$ of soil used for the adsorption test.

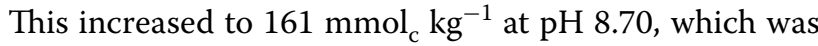
the soil $\mathrm{pH}$ at $689 \mathrm{mmol}_{\mathrm{c}} \mathrm{kg}^{-1}$ of $\mathrm{P}$ adsorption. Therefore, $41 \mathrm{mmol}_{\mathrm{c}} \mathrm{kg}^{-1}$ of the total increase in soil negative charge $\left(44 \mathrm{mmol}_{\mathrm{c}} \mathrm{kg}^{-1}\right.$ ) with $689 \mathrm{mmol}_{\mathrm{c}} \mathrm{kg}^{-1}$ of P adsorption was caused by an increase in $\mathrm{pH}$-induced negative charge and $3 \mathrm{mmol}_{\mathrm{c}} \mathrm{kg}^{-1}$ of that was originated from an increase in $\mathrm{P}$-induced negative charge. Therefore, contributions of the increase in $\mathrm{pH}$-induced negative charge and $\mathrm{P}$-induced negative charge to the total increase in soil negative charge with $689 \mathrm{mmol}_{\mathrm{c}} \mathrm{kg}^{-1}$ of $\mathrm{P}$ adsorption were 93.2 and $6.8 \%$, respectively.

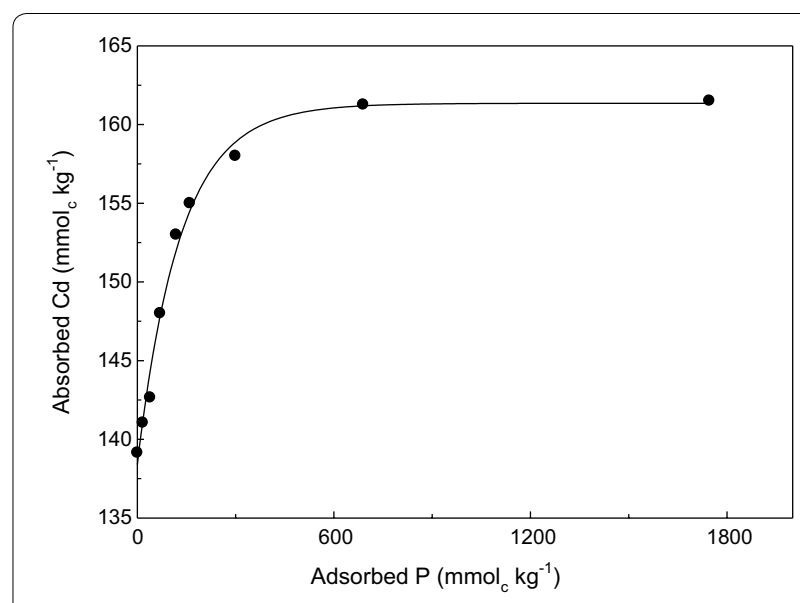

Fig. $5 \mathrm{Cd}$-adsorption to phosphate adsorbed soil after reacting with $500 \mathrm{mg} \mathrm{Cd} \mathrm{L}^{-1}$ of $\mathrm{CdCl}_{2}$ solution at $25^{\circ} \mathrm{C}$ 
Table 3 Correlation coefficients between each parameter

\begin{tabular}{lllll}
\hline Parameter & Cd adsorption & Final pH & Negative charge & P adsorption \\
\hline Cd adsorption & 1.000 & $0.934^{* * *}$ & $0.841^{* *}$ & 0.599 \\
Final pH & & 1.000 & $0.977^{* * *}$ & $0.763^{*}$ \\
Negative charge & & 1.000 & $0.830^{* *}$ \\
Padsorption & & & 1.000
\end{tabular}

* ,, , and ${ }^{* * *}$ represent significance at the $0.05,0.01$, and 0.001 levels, respectively

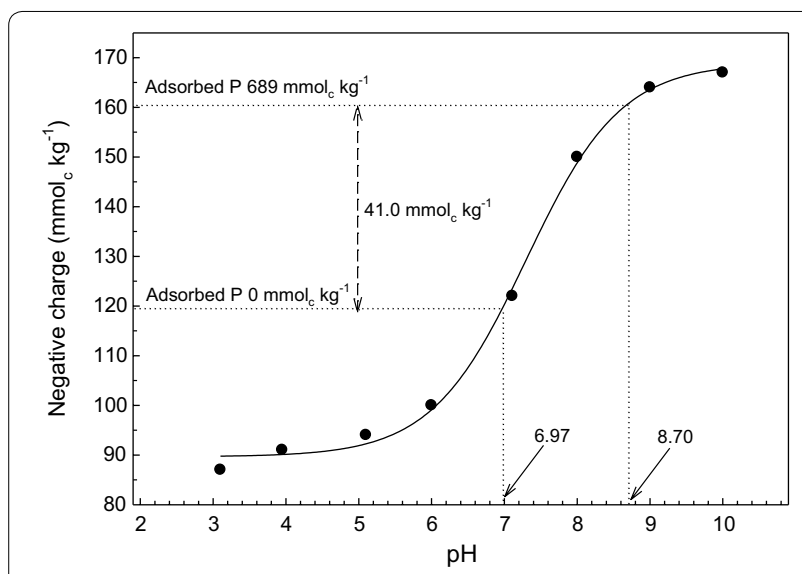

Fig. 6 Changes in negative charge after adjusting pH of clay loam soil

In conclusion, $\mathrm{Cd}$ might precipitate as $\mathrm{Cd}_{3}\left(\mathrm{PO}_{4}\right)_{2}$ under extremely high $\mathrm{P}$ addition $\left(16,000 \mathrm{mg} \mathrm{Pkg}^{-1}\right)$. The formation of $\mathrm{Cd}$ minerals might not occur with $\mathrm{P}$ under the recommended field application rate of $\mathrm{P}$ fertilizer. Cd solubility might be controlled by another mechanism rather than precipitation under low $\mathrm{P}$ application systems. Phosphate adsorption increased the soil negative charge and $\mathrm{Cd}$ adsorption. Contributions of the increase in $\mathrm{pH}$ and P-induced negative charges to the total increase in soil negative charge were 93.2 and $6.8 \%$, respectively. The concurrent increase in $\mathrm{Cd}$ adsorption with $\mathrm{P}$ adsorption was mainly attributed to the increase in $\mathrm{pH}$-induced negative charge.

\section{Acknowledgements}

This work was supported by a 2-Year Research Grant of Pusan National University.

\section{Authors' contributions}

CR and SUK carried out soil sampling, soil analyses, and data organization. $\mathrm{COH}$ participated in interpreting the obtained results and organizing the manuscript. All authors read and approved the final manuscript.

\section{Funding}

Not applicable.

\section{Availability of data and materials} Not applicable.

\section{Competing interests}

The authors declare that they have no competing interests.

\section{Author details}

${ }^{1}$ Department of Life Science and Environmental Biochemistry, Pusan National University, Miryang 50463, Republic of Korea. ${ }^{2}$ Life and Industry Convergence Research Institute, Pusan National University, Miryang 50463, Republic of Korea.

Received: 11 May 2020 Accepted: 30 June 2020

Published online: 10 July 2020

\section{References}

1. Takijima Y, Katsumi F (1973) Cadmium contamination of soils and rice plants caused by zinc mining IV. Use of soil amendment materials for the control of Cd uptake by plants. Soil Sci Plant Nutr 19:235-244

2. Cao RL, Huo WR, He ZL, Hu AT, Deng BE (1993) Study on controlling cadmium pollution in paddy soil in Luo Quio township, Dayie county. China Environ Sci 3:433-439

3. Hong CO, Lee DK, Chung DY, Kim PJ (2007) Liming effects on cadmium stabilization in upland soil affected by gold mining activity. Arch Environ Contam Toxicol 52:496-502

4. Hong CO, Chung DY, Lee DK, Kim PJ (2010) Comparison of phosphate materials for immobilizing cadmium in soil. Arch Environ Contam Toxicol 58:268-274

5. Kim SU, Owens VN, Kim SY, Hong CO (2017) Effect of different way of bottom ash and compost application on phytoextractability of cadmium in contaminated arable soil. Appl Biol Chem 60:353-362

6. Lee HH, Heo DY, Han HR, Park YL, Ruangcharus C, Kim SU, Seo DC, Oh TK, Hong CO (2019) Evaluation of the effects of mandarin (Citrus reticulate) by-products containing citric acid on immobilization of cadmium in arable soils. Appl Biol Chem 62:45

7. Levi-Minzi R, Petruzzelli G (1984) The influence of phosphate fertilizers on Cd solubility in soil. Water Air Soil Pollut 23:423-429

8. Naidu R, Bolan NS, Kookana RS, Tiller KG (1994) lonic strength and pH effects on the adsorption of cadmium and the surface charge of soils. Eur J Soil Sci 45:419-429

9. Jeanjean J, Fedoroff M, Faverjon F, Vincent U, Corset J (1995) Influence of $\mathrm{pH}$ on the sorption of cadmium ions on calcium hydroxyapatite. J Mater Sci 30:6156-6160

10. Mandjiny S, Matis KA, Fedoroff M, Jeanjean J, Rouchaud JC, Toulhoat N, Potocek V, Maireles-Torres P, Jones D (1998) Calcium hydroxyapatites: evaluation of sorption properties for cadmium ions in aqueous solution. J Mater Sci 33:5433-5439

11. Hong CO, Owens VN, Kim YG, Lee SM, Park HC, Kim KK, Son HJ, Suh JM, Lee YB, Kim PJ (2014) Comparative effect of two different types of phosphate on cadmium uptake by radish (Raphanus sativa L.) grown in arable soil affected by mine activity. Commun Soil Sci Plant Anal 45:1133-1148

12. Street JJ, Sabey BR, Lindsay WL (1978) Influence of pH, phosphorus, cadmium, sewage sludge and incubation time on the solubility and plant uptake of cadmium. J Environ Qual 7:286-290

13. Hong CO, Owens VN, Kim YG, Lee SM, Park HC, Kim KK, Son HJ, Suh JM, Kim PJ (2014) Soil pH effect on phosphate induced cadmium precipitation in arable soil. Bull Environ Contam Toxicol 93:101-105 
14. Bolan NS, Adriano DC, Mani P, Duraisamy A, Arulmozhiselvan S (2003) Immobilization and phytoavailability of cadmium in variable charge soils. I. Effect of phosphate addition. Plant Soil 250:83-94

15. Wang B, Xie Z, Chen J, Jiang J, Su Q (2008) Effects of field application of phosphate fertilizers on the availability and uptake of lead, zinc and cadmium by cabbage (Brassica Chinensis L.) in a mining tailing contaminated soil. J Environ Sci 20:1109-1117

16. ME (2005) The Korean soil environmental conservation act. ME, Gwacheon

17. Allison LE (1965) Organic carbon. In: Black CA (ed) Methods of soil analysis. Part II, chemical and microbiological properties. American Society of Agronomy Inc Publishing, Madison, pp 1367-1376

18. RDA (1988) Methods of soil chemical analysis. National Institute of Agricultural Science and Technology RDA, Wanju

19. Schofield RK (1949) Effect of $\mathrm{pH}$ on electric charges carried by clay particles. J Soil Sci 1:1-8

20. Murphy J, Riley JP (1962) A modified single solution method for the determination of phosphate in natural waters. Anal Chem Acta 27:31-36
21. Lindsay WL (1979) Chemical equilibria in soils. Wiley, New York

22. Sparks DL (2003) Environmental soil chemistry. Academic Press, Newark

23. Santillian-Medrano J, Jurinak JJ (1975) The chemistry of lead and cadmium in soil: solid phase formation. Soil Sci Soc Am Proc 39:851-856

24. Street JJ, Lindsay WL, Sabey BR (1977) Solubility and plant uptake of cadmium in soils amended with cadmium and sewage sludge. J Environ Qual 6:72-77

25. RDA (1999) Recommendation standard of fertilization for crops. National Institute of Agricultural Science and Technology RDA, Wanju

26. McBride MB (1994) Environmental chemistry of soils. Oxford University Press, New York

\section{Publisher's Note}

Springer Nature remains neutral with regard to jurisdictional claims in published maps and institutional affiliations.

\section{Submit your manuscript to a SpringerOpen ${ }^{\circ}$ journal and benefit from:}

- Convenient online submission

- Rigorous peer review

- Open access: articles freely available online

- High visibility within the field

- Retaining the copyright to your article

Submit your next manuscript at springeropen.com 